\title{
The Architectural Appropriation of the Apostle Peter by the Early Christian Popes
}

\author{
Kristina Friedrichs
}

In terms of Christian values and ideals in the early centuries CE, Peter is generally regarded as one of the most important apostles, and in particular for the urban community of Rome itself. Peter was used as an icon to convey an ideology to support political goals directly or indirectly. One means for achieving this is through art and architecture. This essay explores this phenomenon by addressing two central enquiries:

(i) What does the concept of architectural appropriation imply and how is it integrated in the process of anchoring innovation? How did this relationship develop between the 2nd and 6th centuries? (ii) Who are the protagonists of this development and what was their motive to use Peter as an anchor? This paper describes an approximate model of architectural appropriation deduced from the results obtained in addressing these enquiries.

There are several places in the city of Rome associated with Peter: First, of course, the supposed grave site of Peter on the Vatican hill; secondly, the place where Peter and Paul lived and where their skulls, according to legend, were kept during the time of persecution, under the present Basilica of San Sebastiano. In addition to these places, no other physical sites to revere Peter were established in and around Rome, except for San Pietro in Vincoli. This article, however, focuses exclusively on the Vatican and San Sebastiano, as there are many architectural activities to retrace.

Architectural appropriation in this context means the intentional use of architecture or architectural decoration in order to achieve particular political or societal goals. This observation is closely linked to the concept of anchoring innovation. In fact, architectural appropriation can be a kind of anchorage. The conceptual basis of anchoring was laid down by Sluiter in 2017; she stated that anchoring innovation is the successful implementation of something new to a defined social group by conveying that this innovation is based on something old and long known. ${ }^{1}$ The same can be said of architectural appropriation: it

1 'Anchoring is the dynamic through which innovations are embedded in and attached to what is (perceived as) older, traditional, or known. "Anchors" are the concrete phenomena 
involves a process in which a well-established tradition is evoked, thereby enabling the target group to readily accept and support a political situation. ${ }^{2}$ In both cases, however, there exists the risk that the innovation may not find approval by the target group if the historical construct is lacking in acceptance.

There are, however, differences between these two concepts. While anchoring can be controlled both consciously and unconsciously, ${ }^{3}$ architectural appropriation is always an active process, in which the protagonists are clearly identifiable. Installing a new anchor can even occur spontaneously, whereas in the case of appropriation, this anchor must be concretized subsequent to its introduction. This allows us to draw conclusions regarding the introduction and genesis of an anchor. In this case, the apostle Peter serves as an anchor.

This paper describes a three-phase model that retraces the development of architectural appropriation in chronological order. The development begins with the first appearance of what is going to become the anchor later on; an accumulation of content follows, until a point is reached where it is recognized that this anchor can be implemented to achieve contemporary political goals. This paper deals primarily with the social and political motives in the early centuries CE in Rome, which places this work in the category of metalevel discourse. Archaeological findings and written evidence would be required to substantiate or invalidate the premises described herein. This paper does not examine the dates and attributions, which have been discussed extensively and sometimes controversially elsewhere in published research. The reader, however, is referred to the corresponding literature where relevant.

\section{Stage 1: Peter on the Rise}

The first architectural monument dedicated to Peter dates back to the 2nd century, and thus to a time when the Christian Church, as an institution, had neither been consolidated nor established its organization internally. It is supposed that around the year 160 a community leader from the ranks of the local clergy was elected. ${ }^{4}$ Nevertheless, the process of differentiation of the church hierarchy was not yet complete. Until the time of the Constantinian shift, it

or concepts that are perceived or experienced as the stable basis for innovation': Sluiter (2017) 11.

2 Assmann (1999) 63-5.

3 Sluiter (2017) 1.

4 Ignatius of Antioch Smyrn. 8.1f. Some authors argue in favor of a later dating in the last decades of the second century: see Zwierlein (2009) 183-215 and Handl (2016). 
can be assumed that construction activities remained limited and concentrated on sepulchral architecture.

In the second half of the 2nd century, probably after 16o, the well-known aedicula was erected on the supposed tomb of Peter on the Vatican hill. It consisted of a niche that was embedded within existing structures and limited to two columns, one at each side. ${ }^{5} \mathrm{~A}$ written source bears testimony to the structure: Gaius, a member of the Roman community, wrote around the year 200: 'But I can show the trophies of the apostles. For if you will go to the Vatican or to the Ostian Way, you will find the trophies of those who laid the foundations of this church.6 In this context, the trophies serve as proof of the purity of Roman doctrine. No mention is made regarding the appearance of the place, but the term tropaion denotes a factual place associated with martyrdom or the tomb itself.

Considering the process of architectural appropriation and the extent to which an innovation has been anchored, two things are notable: First, it is neither known from written sources, nor from archaeological evidence who exactly the architect of this site was. On the one hand, the Christian community as an institution could be considered as the initiator of the construction project. On the other hand, wealthy private individuals are conceivable. ${ }^{7}$ The question to which extent this work was linked to the bishop has not been finally answered. ${ }^{8}$

Without naming the protagonist exactly, two things can be stated: firstly, a place was required to commemorate the apostle and founder of Rome's community, and to accommodate a powerful saint. Secondly, the establishment of a memorial in honour of an (outstanding) deceased person corresponds to the general values of the Roman society of that time. The veneration for Peter probably played a major role in this case.

The same can be said for the memorial on the Via Appia Antica, which was excavated below San Sebastiano. According to common belief, Peter and Paul resided here. Since the 1st century a cemetery existed here and was still in use

5 Apollonj Ghetti et al. (1951) 107-44 and CBCR V (1967) 177, 182-3. See also Arbeiter (1988), 30-1 for the various reconstructions.

6 Eusebius, Hist. eccl. II.25.5. Arbeiter (1988) 18-9.

7 For the juridical situation concerning church property see Bowes (2008) 64 .

8 While Guarducci (1967) 56 wanted to see the pope as an individual as the guardian of the tomb of Peter and justified this with the oral or personal tradition and the temporal proximity, Dassmann (1994) 52 proved that the monepiscopate is indeed detectable by 150 and thus a single person possibly could have decided on construction projects. However, it was not yet a monarchical episcopate, which again limited this idea. Cf. Kritzinger (2016) 24-43 and Schölgen (1986). Thümmel (1999) 96-8 also noted that communities in particular played a major role in remembering the dead. 


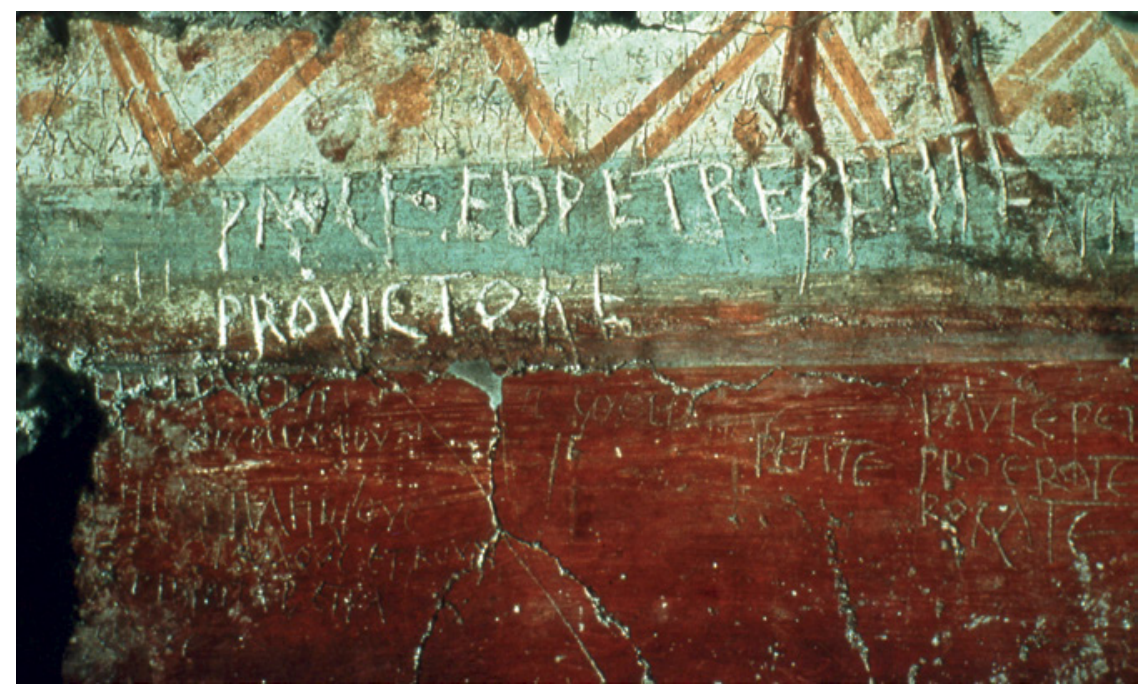

FIGURE 12.1 Inscription in the triclia below S. Sebastiano ad catacumbas

into the 3 rd century. Around $250-260$ a place of worship was created, the memoria apostolorum, for both apostles. ${ }^{9}$ A roofed area was created in proximity to the older tombs, which served to commemorate the dead, thereby offering protection from the weather. More than 600 inscriptions dedicated to Peter and Paul bear witness to the great veneration that was given to the two apostles in this place (fig. 12.1). ${ }^{10}$ In acts of personal piety, the saints were called upon and asked for intercession.

Neither archaeological nor written sources are available that reveal who was responsible for the construction of the pergola. However, the inscriptions are evidence that this place developed into a place of worship for the laity without major external control. Architecturally, the structure corresponds to the well-known triclia, a place for funeral banquets, ${ }^{11}$ but without any specially developed typology. The place of worship thus corresponded to the typical Roman tradition of honouring outstanding personalities of the past and thus conformed to already familiar patterns.

Few monuments belong to this very early phase of architectural appropriation of Peter. Especially important was the exceptional role of the saint

$9 \quad$ Arbeiter (1988) 49-50, Jastrzebowska (2002) 1145-7, CBCR IV (1970) 112-8.

10 See also the contribution by Van den Hoek to this volume.

11 Diefenbach (2007) 41-55 and 155-64. 
as apostle and founder of the Roman community, who as a major saint could have been a strong personal advocate. It is not known to what extent the church as an institution became active as a protagonist in this development. Scholarship has so far not been able to reveal, by name, a single protagonist which enacted this appropriation process. Peter, not yet being an anchor, was therefore not an actor to install an innovation. Rather, it seems that already known traditions were more likely to have been used to anchor Peter's special role. Well-known burial traditions were therefore used to support the evolving trend.

\section{Stage 2: Petrus Becomes an Anchor}

After the Constantinian shift, major changes took place. An architectural appropriation in the narrower sense occurred as a result of a Christian architecture becoming possible. Nevertheless, it was mostly Emperor Constantine, members of the imperial family or the aristocracy who founded many new churches. ${ }^{12}$ These new buildings either enabled the continuation of a cult at their construction site or the establishment of new traditions. The construction of the episcopal church at the Lateran falls into this period..$^{13}$ At the same time, the institutionalization of the church progressed, both in terms of the differentiation of the clergy and the construction activities. The secular founders involved the clergy. This is documented towards the end of the 4th century.14 It is also known that the construction process was supervised by the clergy. For example, when Bishop Damasus erected the baptistery of Old St Peter's, he instructed the presbyter Mercurius to supervise the installation of the water channels. ${ }^{15}$ At this point, the question regarding the architectural appropriation of Peter becomes important: how complete was the level of architectural appropriation? Who were the protagonists of this development and what were their aims? Which innovation required an anchor?

\footnotetext{
12 Leeb (1992) 71-85.

13 For the Christian topography of Rome see Krautheimer (1983) 7-40. This opinion was limited by Brands (2003) 10-6 and Diefenbach (2007) 83-130.

14 The case best known is the letter of the emperors Valentinian, Theodosius and Arcadius addressed to the praefectus urbi, giving the instruction to consult the bishop: Collectio Avellana 3. Gelasius later regulated new constructions so that the bishop's approval always had to be obtained (ep. 33).

15 Ferrua (1942) no. 3. Further examples: Friedrichs (2015) 110-112.
} 
A first example is the Basilica of San Sebastiano, which was built at the beginning of the 4th century above the place of worship for Peter and Paul, as a three-nave building with a semi-circular apse. ${ }^{16}$ The consecration to Saint Sebastian took place only in the 9th century. The Basilica Apostolorum took over the function of the former memoria, where the dead could be commemorated and the worship of apostles could take place on a larger scale. ${ }^{17}$ The construction therefore remained functional within the usual traditions, but possessed the capacity for larger events. The building was financed by the imperial family. Besides this well-known site for the two apostles, many other Roman saints were also provided with their own churches, among them Agnes, Marcellinus and Petrus as well as Laurentius. ${ }^{18}$ There was therefore no exclusive focus on the two apostles or Peter in particular.

On the contrary, however, the emperor had Peter's alleged grave built around 320 to 327 with a monumental basilica 213 meters long and 63 meters wide (fig. 12.2), ${ }^{19}$ which emphasised the significance of the apostle's tomb. Only the episcopal church at the Lateran could boast with similar dimensions. Not only was the sheer size of the church extraordinary, but also its use as a place of pilgrimage clearly dictated its architectural layout with four aisles, transept and atrium with a colonnade. Particularly striking to observe is how the grave and altar are architecturally combined. In other memorial churches such as S. Agnese and others, the church was always erected near the catacomb, but not directly above the tomb, as this would have disturbed both the holy peace of the dead and also Roman law. ${ }^{20}$ That this solution was chosen for Peter's sepulchre demonstrated the particular importance that was associated with him. The church above Paul's sepulchre was also designed with a similar arrangement, but the Constantinian construction remained in much smaller dimensions, thereby emphasizing the importance of Peter in particular.

For Constantine various motives for this focus seems to have been crucial. Peter was one of the most important apostles. According to the interpretations of the Roman Church, Peter was even considered as the head of this circle. For the emperor, Peter was already suitable as an anchor for an innovation: When Constantine opted for the Christian religion, he chose Christ as his personal

\footnotetext{
$16 \quad C B C R$ IV (1970) 118-46, Jastrzebowska (2002) 1148-55.

17 La Rocca (2002) $1117-8$.

18 LP 34.23-26. See LTUR Sub 1 (2001) 33-6 for S. Agnese fuori le mura, LTUR Sub 4 (2007) 19-25 for SS. Marcellino e Pietro, and LTUR Sub 3 (2005) 203-11 for S. Lorenzo fuori le mura.

19 Brandenburg (2017) 48-52. CBCR V (1967) 165-286.

20 Diefenbach (2007) 162-3 and De Blaauw (2001) 973-80.
} 


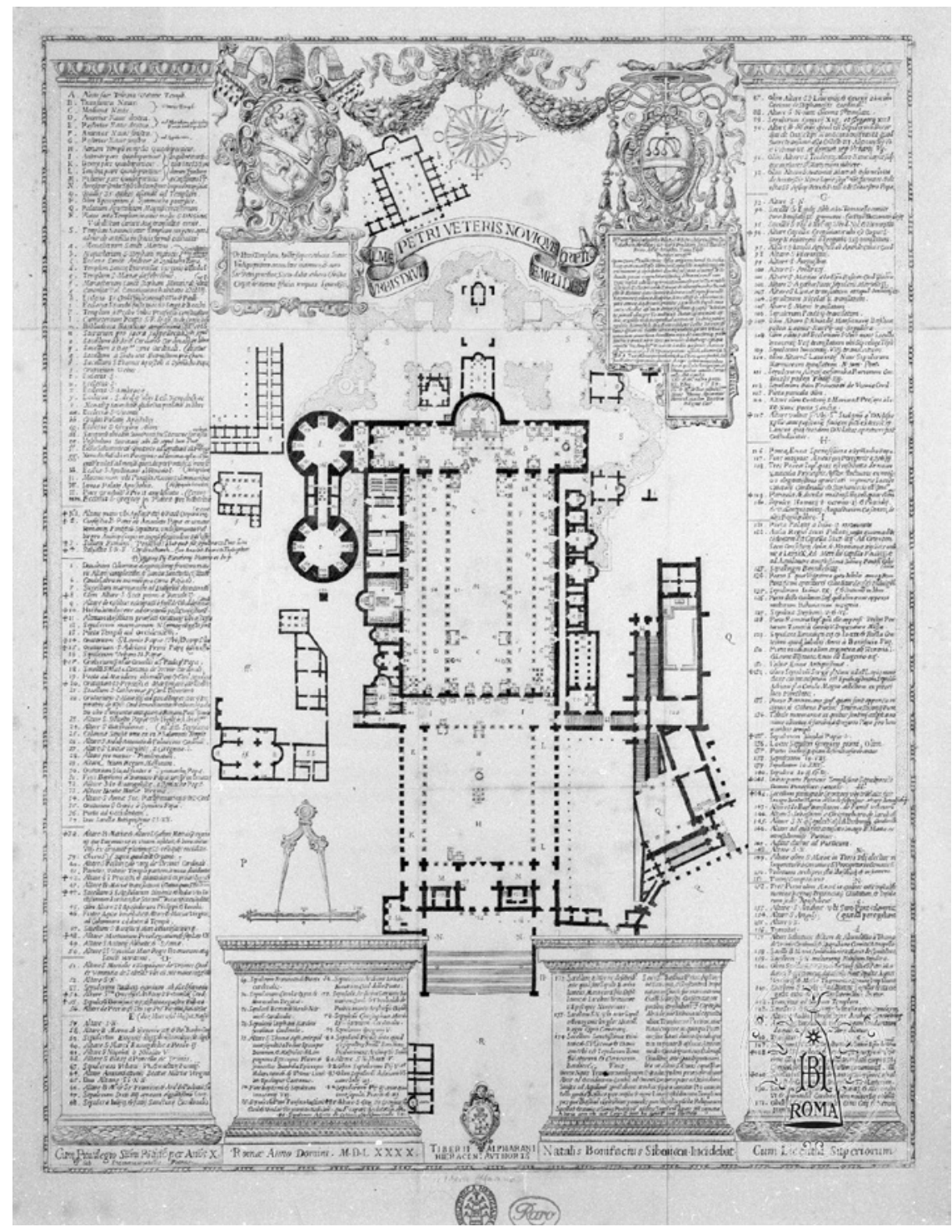

FIGURE 12.2 Ground plan of Old St Peter's. Tiberius Alpharanus: Almae urbis divi Petri veteris novique templi descriptio / Tiberii Alpharani Hieracen, authoris. Natalis Bonifacius Sibenicen. Incedebat, around 1590 
comes and the highest saints as his personal advocates. ${ }^{21} \mathrm{He}$ had to explain this shift to a particular God - the Christian one - to both Christians and nonChristians. He was able to demonstrate this to Christians through the construction of the churches and the consecration to certain saints, for example through St Peter's or the Lateran church dedicated to the Saviour. On the other hand, he took into account the traditions of the pagans (but not their values regarding Christianity) by following the typical patterns of personal piety, which could also be expressed through the activities of foundations. In his case, this took place at a high level in accordance with his rank. This was not devised with the objective of promoting the Roman bishop, who would later become important, but rather to accentuate the imperial founder himself. Thus, the church of Old St. Peter is an early example of architectural appropriation of Peter: The apostle was not only perceived as important as a possible anchor, but was also used for imperial self-expression and thus already succeeded as an anchor. Other places of representation and their saints, however, had the same function.

Half a century later, bishop Damasus $(366-384)$ dictated a different direction. A schism overshadowed his inauguration and caused unrest in the community for years. ${ }^{22}$ He therefore had to resort to extraordinary measures to represent himself. His solution was to use the Roman saints as support. In the catacombs he carried out extensive constructions, all of which were adorned with praiseworthy inscriptions of the saints, including of himself. ${ }^{23}$ One of the best known examples is that at the memoria apostolorum:

Hic habitasse prius sanctos cognoscere debes, nomina quisque Petri pariter Paulique requiris.

Discipulos oriens misit, quod sponte fatemur; Sanguinis ob meritum Christumque per astra secuti Aetherios petiere sinus regnaque piorum. Roma suos potius meruit defendere cives. Haec Damasus vestras referat nova sidera laudes. ${ }^{24}$

21 In Constantinople, a similar action was taken by the emperor when he developed the cult of Andrew, but of course with another background than in Rome, see Leeb (1992) 90-118.

22 Reutter (2009) 31-56.

23 Diefenbach (2007) 289-324 and Reutter (2009) 80-98.

24 Ferrua (1942) no. 20. 'Here the saints abided previously. You ought to know this, whoever you are, you who seek equally the names of Peter and Paul. The East sent the disciples, which we acknowledge freely. On account of the merit of their blood and having followed Christ through the stars, they have traveled to the bosom of heaven and the kingdom of 
Besides the common topoi of Damasus, the above-mentioned inscription is particularly interesting, because it celebrates Peter and Paul as the new stars of Rome and thus as the successor of the Dioscuri. Nevertheless, it remained within the usual wording of the Damasian inscriptions..$^{25}$ Although Peter was worshiped as a special saint, the real anchor that would help support the bishop's acceptance was the entire group of Christian saints.

The construction of a baptistery at the Vatican was clearly more focused on Peter. When Damasus became active here, probably with the assistance of the noble lady Anastasia, not many possibilities for baptism existed in the city of Rome. ${ }^{26}$ Even though the baptistery cannot clearly be located, the right arm of the transept, an annex to the transept or an independent building in the immediate vicinity come into question. ${ }^{27}$ The Gesta Liberii report that Damasus set up the baptistery at the Vatican. ${ }^{28}$ Furthermore, the Peristephanon Liber of Prudentius yields a vague description that gives the impression of splashing water, reflecting mosaics and a marble basin. ${ }^{29}$ At this time, the Roman community was baptized at the Lateran, which implies that this baptistery at the Vatican should have been primarily intended for pilgrims, who wanted to be baptized at this particular site. Here too, Damasus had an inscription attached, praising Peter as a saint and presenting himself as the founder. The inscription remained within the usual parameters mentioned above. ${ }^{30}$ The architecture was primarily of a practical nature, so that although an architectural appropriation took place, this only partially used Peter as an anchor in order to politically stabilize the pontificate of Damasus. On the one hand, this was probably due to the fact that other protagonists, such as the imperial family and the Roman aristocracy, were also very active in the Vatican during this time. ${ }^{31}$ On the other hand, Damasus did not especially need to emphasise Peter, because the sheer mass of saints used for this was a much more effective method to achieve episcopal representation.

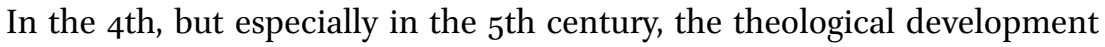
of a doctrine of Peter accelerated. The emphasis on Paul, on the other hand,

the righteous. Rome capably deserved to watch over its own citizens. Damasus records these things for your praise.' Translation by Eastman (2011) 101.

25 Ferrua (1942) 144 and Reutter (2009) 150.

26 Bruderer Eichberg (2002).

27 See Schumacher/Barth (1986), Smith (1988), Alchermes (1995) as well as Brandenburg 2017, 24. Cf. also 6, Brandenburg (2003), Trinci Cecchelli (1983) 182-87.

28 The Gesta (PL 8.1388) only date into the 6th century and thus their reliability is limited.

29 Perist. 12.33-44. As Brandenburg (2003) suggested, those lines could also refer to a cantharos in the atrium of the basilica.

$30 \quad$ Ferrua (1942) no. 3 and 4.

31 Videbech (2017) 1-3. 
increased in the last decades of the 4 th century. ${ }^{32}$ The theological discourse emphasized the extraordinary fact that the Roman community had been established not by one, but by two apostles, thus exalting the bishop seat out of the others. ${ }^{33}$ In architecture, this was expressed by constructing a monumental replacement of the church on Via Ostiense, which was built by the Roman emperors. In this context, Paul was actively developed as an anchor in a relatively short time. Even though the project was led by the emperors and only subordinately by the bishop, who was a kind of "first consultant", ${ }^{34}$ the coordinated construction project should be useful for the latter.

Peter, nevertheless, remained the mainstay of Roman discourse, especially in theological matters. During the pontificate of Leo I, the focus was redirected towards Peter, who was emphasized not only as the founder of the Roman community, but as the highest of the apostles, deputy of Christ on earth and the beginning of Roman episcopal succession. ${ }^{35}$ Ideally, these conceptual constructs should have an impact on the prevailing political situation. Within this context, it becomes apparent that Peter is explicitly used as a stabilizing anchor to justify the growing demand of power by the Roman bishop. When one considers this development, the question arises whether the architectural appropriation by the bishop reached a new dimension.

It is possible to draw conclusions from the information in the Liber Pontificalis concerning the donations and foundations of the popes. ${ }^{36}$ With regards to Leo I, four factors can be identified: First, he had to replace the liturgical objects that had been lost during the vandal invasion. Second, during his tenure, Leo had a church built on the Via Appia dedicated to beato Cornelio episcopo et martyri. Both were measures that belonged to the typical duties of a community leader. Third, he founded a new monastery near St Peter's and found his own final resting place near that of the apostle. The combination of a burial site and a monastery, in which intercession is provided for its founder, suggests

32 Grig (2004a) 203-30.

33 Friedrichs (2015) 68-73. Both apostles' death was even commemorated with a joint celebration on June 29th. Contemporary sources mention this event: Prudentius, Perist. 12; Ambrosiaster, In Epistolam Beati Pauli ad Romanos 2,7,8 in PL 17.45-184, CSEL 81.1.

34 A discussion about the authority and power of co-determination of the bishop can be found at Kritzinger (2016) 150-8. Lucherini (2016) 67 also estimated the financial resources of the Roman bishops in the 4th century as too low to become architecturally active on a large scale.

35 Leo, ep. 10 (PL 54.551-1218) used the Roman inheritance law, Tituli ex corpore Ulpiani 20.1. Maccarone (1991a) 261-74, Ullmann (1960). The political claim to power of the popes reached its peak at the end of the 5 th century: Felix III., ep. 9 ( $P L 5^{8.934-6)}$, written by Gelasius. Gelasius, ep. 8 (PL 59.13-140). Ullmann (1981).

$36 \quad$ LP I.238-41. 
a significant personal connection with this chosen saint. Fourth, both the large basilicas, St Peter's and St Paul's, were renovated.

St Paul's was probably damaged by lightning. It is not possible to exactly ascertain the extent of the restoration, but it seems to concern mainly the central area of the nave. ${ }^{37}$ The clerestory walls were adorned with extensive fresco cycles, which are dated by most scholars to the pontificate of Leo I. ${ }^{38}$ In the following centuries, of course, these were repeatedly restored and altered, and were almost completely destroyed by a severe fire in 1823 . The basis of investigation, therefore, is quite fragmentary. One the most interesting parts of the decoration includes the series of papal portraits that adorned the walls of the clerestory. All Roman bishops, including Leo I, were depicted in a uniform manner in a homogeneous series of ecclesiastical dignitaries (fig. 12.3). ${ }^{39}$ This coincides with the idea of apostolic succession introduced by Leo, in which the following bishop was identical with his predecessor. Such a "sense of continuity" is a particular characteristic of "anchors" ${ }^{40}$ In the case of secular rulers, this could be done through inheritance. For the Roman bishops this was achieved through the idea of succession. Thus, the cycle begins with Peter, followed the tradition of the written lists of bishops - a practice that was already in use for about three centuries. ${ }^{41}$ Thus, the clerestory walls in St Paul's emphasize the papal office that arose from Peter as the theological basis. This clearly demonstrates that Leo used Peter as an anchor, especially associating him with the concept of an established tradition, already embedded in the minds of the people. In this way, Leo was able to justify the extensive demand for power by the papal office. This was a case of a deliberate, as well as an intellectually mature appropriation of Peter by means of images in an architectural context. At about the same time, a major restoration was undertaken to St Peter's by Leo I. ${ }^{42}$ Lay people Marinianus and his wife Anastasia were involved in decorating the façade. Here too, the walls of the clerestory were painted with a cycle of papal portraits, analogues to St Paul's, which depict the Roman bishop uniformly in a row with Peter as the starting point of the succession. Again,

37 CBCR V (1967) 93-164, also Kessler (2004) and Brandenburg (2005) 124f. Cf. ICUR 2.4783; 2.4958 .

38 Friedrichs (2015) 215-24, Andaloro (2006) 366-95, Pöpper (2004), Ladner (1941) and De Bruyne (1934). Gianandrea (2016), who prefers a Constantinian dating, spoke recently against dating to the $5^{\text {th }}$ century. For the further history of the paintings and their iconography cf. Proverbio (2016).

39 Cod. Barb. Lat. 4407.

$40 \quad$ Sluiter $(2017) 4$.

41 For further reading about the bishop lists see Caspar (1926), Klauser (1974) and Maccarone (1991a).

$42 \quad C B C R$ V (1967) 165-286, Friedrichs (2015) 226-31 and Andaloro (2006) 416-8. 


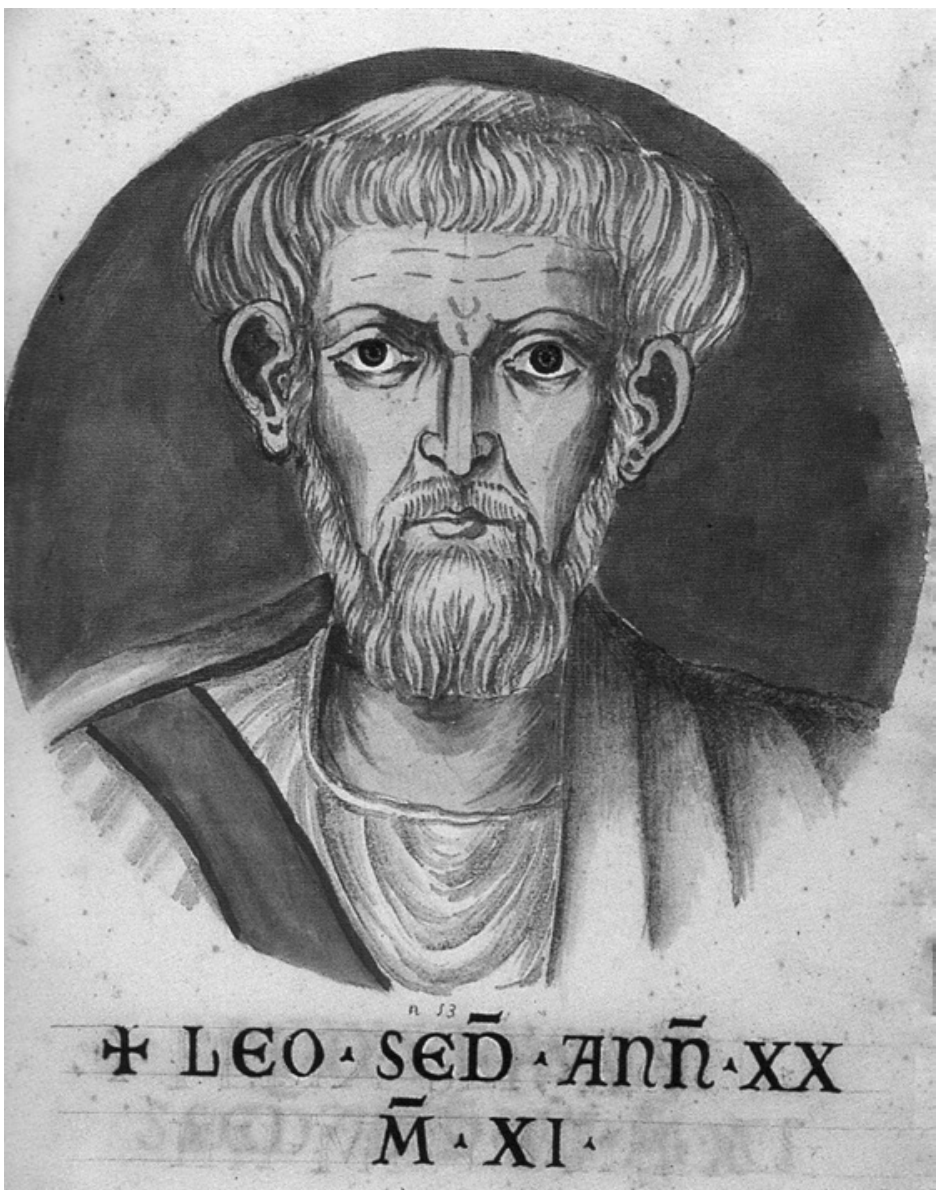

Figure 12.3 Biblioteca Apostolica Vaticana, Barb. lat. 4407, Antonio Eclissi: Effigie di settantotto Pontifici dipinti intorno alla basilica di San Paolo, 1634 , fol. 46

the focus was on the papal office, not on the individuals. Thus, in two of the most prominent places in Rome, Leo visualized his elaborate idea of so-called "Petrinology", consciously acquiring Peter and using this as an anchor for his ideas as described above.

As indicated at the beginning, Peter was not only of theological and political importance as an anchor for Leo, but the pope also showed a great personal connection with the saint. For this reason, the bishop chose a place near the relics of the apostle, where he had his own burial site created. An additional monastery was founded in order to preserve the memory of its founder. Both 
structural measures show, in contrast to the examples above, no architectural appropriation of Peter. Rather, these were privately motivated foundations that Leo used to ensure his own life after death. It was not a decision from the papal administration..$^{43}$

The two non-privately motivated foundations, on the other hand, are based on the significance of Peter within the theological ideas Leo had, whereby the written and pictorial-architectural concepts become congruent. The architectural appropriation by a holder of the papal office reached new heights under Leo: in this case, Peter was used as an indirect anchor to justify the superiority of the popes to other bishops. One could back up this special position via theology and via the (supposedly) grown tradition; architectural appropriation followed as a consequence of these lines of thought.

\section{$3 \quad$ Stage 3: Representation through Peter}

At the beginning of the 6th century, the idea of apostolic succession and the political consequences derived from it were already well developed. In the first decade of this century, one case reveals that the apostle Peter could be used as an anchor for political purposes, regardless of the theological basis. This case involves bishop Symmachus, who used Peter's grave to stage himself as a true leader of the Roman community.

The background to this case involved the schism with Laurentius, which persisted for several years. In order to bring about a solution, the Roman community had to resort to including the secular offices. For a long time, Symmachus lived in exile from the city and was only recognized as the rightful bishop in $506 .{ }^{44}$ Under these circumstances, he and his followers had to come to terms with the existence outside the city walls. Whatever architectural measures were taken, they had to be chosen in such a way as to create a good reputation for Symmachus. ${ }^{45}$

Symmachus chose St Peter's as the place of his residence. ${ }^{46}$ From the Liber Pontificalis it is known that he took several measures to adapt the place to his needs for the residential and administrative functions. He donated a church

43 The statement in the Liber Pontificalis that the early Roman bishops were buried close to Peter's grave may not be taken as a hard fact, but is a later projection from the sixth century, see Borgolte (1989) 15-21.

$44 \quad L P$ I.26o-68; Wirbelauer (1993).

45 Cecchelli $(2000) 111-28$.

$46 \quad L P$ 53.6-12. Alchermes (1995) 15 calls St Peter's a 'proper papal showcase'. 
dedicated to the apostle Andrew, which was housed in an existing 4th-century building. Several altars were consecrated to saints whose relics were transferred from other places to Rome. ${ }^{47}$ In the baptistery Symmachus integrated three altars, which were in obvious analogy to the Lateran baptistery consecrated to the Holy Cross, John the Baptist and John the Evangelist. Symmachus had no access to the main baptistery of the community at the Lateran during his exile years. ${ }^{48}$ In addition, Symmachus donated a large number of liturgical objects for the Basilica of Peter. There he built a quadriporticus with mosaics and precious marble, stairways and a public bath. This was an additional monumentalization of the complex, which was also equipped with accommodation for the poor and - as a particularly outstanding project - the bishop's palace as well. All of these construction measures supported his self-portrayal as the legitimate bishop of the city. In addition, this observation is supported by two further construction projects for St Pancras ${ }^{49}$ and St Martin of Tours, ${ }^{50}$ who were known on the one hand as helpers and on the other hand as supporters of the poor. With all these actions, Symmachus presented himself as a philanthropist and a good community leader.

Most of his efforts, however, were put into St Peter's, which was thus transformed into a kind of second episcopal seat. Since the true seat was not accessible, Symmachus had to occupy the latter, emblematic place. On the basis of the station liturgy, as recorded in the Capitulare Lectionum of Würzburg, it is also possible to understand what significance the Vatican had achieved. Eight stations were celebrated in the Lateran, ten in Santa Maria Maggiore, but also eight stations in the Vatican. ${ }^{51}$ These observations emphasize that Symmachus purposely appropriated Peter to achieve a political goal. It is clear that not only was Peter fit as an anchor, but apparently he was considered to be so effective that most of Symmachus's personal representation was based on the apostle. Thus, this was a case of architectural appropriation, as was last encountered under Constantine. The architecture dedicated to the apostle was used to communicate a new, secondary situation and to enforce the bishop's innovation, namely to be recognized as legitimate, even if he did not reside at the Lateran.

47 Alchermes (1995) 9-10.

48 Brandenburg (2003) 67-8.

$49 \quad L P 53.8, C B C R$ III (1967) 153-74.

5o LP 53.9, CBCR III (1967) 87-124.

51 Dated around the middle of the 6th century. See Geertman (1987) and Friedrichs (2015) 135 as well as table 3,290-1. In Carolingian times, the Vatican was visited even 13 times. 
It has been shown that the processes of anchoring innovation and architectural appropriation correlate in some way in the case of Peter. There appear to be several stages of appropriation linked to the acceptance and stability of the anchor.

In the first phase, the anchor is in development, which requires other anchors to enforce it as an acceptable innovation. Existing ideas and values support this process. In our example, Peter was already an outstanding figure as a saint, apostle and founder of the community of Rome, who was initially the object of personal devotion ("Volksfrömmigkeit"). No protagonist can yet be named who willingly used this anchor for his own innovations, but already prevailing trends developed within the context of their historical circumstances without an active agent.

In the second phase, the anchor, in this case Peter and his cult, experiences the formation of an intellectual foundation. The ideas behind the anchor stabilize - and the anchor itself as well. At the same time, an awareness develops that the anchor can be used to underpin other (own) ideas, which leads to the third phase.

At this stage, the anchor is fully established and is used to justify the introduction of an innovation in order to ensure its acceptance and thus to pursue own, more far-reaching goals. At the same time, architectural appropriation can be a means of communication. Accompanying iconographic programs or liturgical ceremonies serve an explanatory purpose and make this process acceptable to the target audience. The anchor itself becomes the medium of transfer.

It is evident that this process is not linear (fig. 12.4). ${ }^{52}$ Rather, it correlates with the historical circumstances, the protagonists involved and the innovations to be anchored. While architectural appropriation under the protagonist Constantine already experienced a first climax, it took much more time for the Roman bishops as protagonists to use this anchor. Examples of other anchors also emphasize the diversity of the development, be it Damasus with the martyrs of the city or Paul in the late 4th century as the second apostle of Rome. Numerous protagonists used Peter in various ways to achieve different goals. Conversely, the architectural appropriation is often evidence that an anchor was considered to work and was given a certain power of persuasion. Above all, the aforementioned Constantine and much later Symmachus are good

52 This is an observation also made by Gianandrea (2016) 103, who mainly looked at the founder's behavior in the Vatican in the fifth century. 

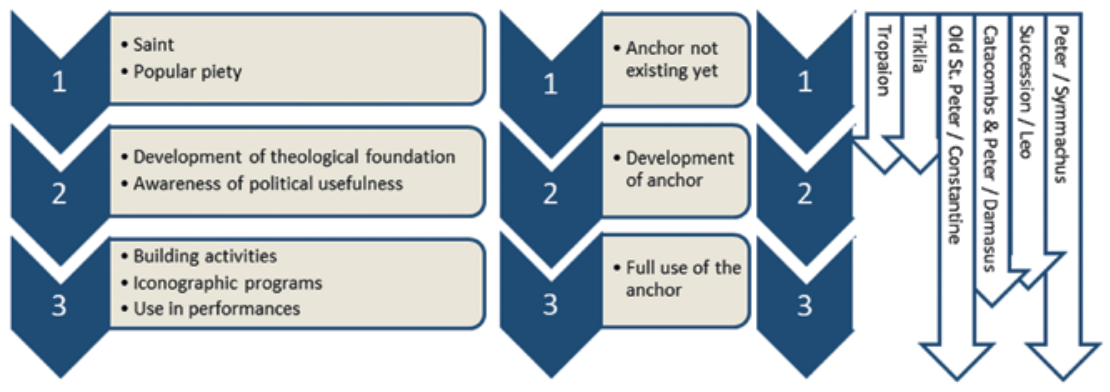

FIGURE 12.4 Idealized scheme of architectural appropriation

examples of the anchoring processes in which Peter has an important role and architecture functions as a medium through which these processes took place.

\section{Bibliography}

Andaloro, M. 2006. L'orizzonte tardoantico e le nuove immagini 306-468. Milano: Jaca.

Arbeiter, A. 1988. Alt-St-Peter in Geschichte und Wissenschaft. Abfolge der Bauten, Rekonstruktion, Architekturprogramm. Berlin: Mann.

Assmann, A. 1999. Zeit und Tradition. Kulturelle Strategien der Dauer. Köln: Böhlau.

Borgolte, M. 1989. Petrusnachfolge und Kaiserimitation. Die Grablegen der Päpste, ihre Genese und Traditionsbildung. Göttingen: Vandenhoeck \& Ruprecht.

Bowes, K. D. 2008. Private worship, public values, and religious change in late antiquity. Cambridge: Cambridge University Press.

Brandenburg, H. 2003. Das Baptisterium und der Brunnen des Atriums von AltSt. Peter in Rom. Boreas 26: $55^{-71 .}$

Brandenburg, H. 2005. Die frühchristlichen Kirchen Roms vom 4. bis zum 7. Jahrhundert. Regensburg: Schnell+Steiner.

Brandenburg, H. 2017. Diekonstantinische Petersbasilika am Vatikan in Rom. Regensburg: Schnell+Steiner.

Brands, G. 2003. Die spätantike Stadt und ihre Christianisierung. In Die spätantike Stadt und ihre Christianisierung, ed. G. Brands \& H. G. Severin, 1-26. Wiesbaden: Reichert. Bruderer Eichberg, B. (2002) Prolegomena zur frühchristlichen und frühmittelalterlichen Tauforganisation Roms. Die Baptisterien und die Stifterrolle der Päpste. In Art, Cérémonial et Liturgie au Moyen Âge, ed. von Bock, N. et al., vol. 1, 321-356. Roma: Viella.

Caspar, E. 1926. Die älteste römische Bischofsliste. Berlin: Deutsche Verlagsgesellschaft für Politik und Geschichte. 
Cecchelli, M. M. 2000. Interventi edilizi di Papa Simmaco. in: Il papato di Simmaco (498-514), ed. G. Mele \& N. Spaccapelo, Natalino, 111-28. Cagliari: Pontificia Facoltà Teologica della Sardegna.

Dassmann, E. 1994 Ämter und Dienste in den frühchristlichen Gemeinden. Bonn: Borengässer.

De Blaauw, S. 2001. L'altare nelle chiese di Roma come centro di culto e della committenza papale. In: Roma nell'alto medioevo, 969-9o. Spoleto: La sede del centro.

De Bruyne, L. 1934. L'antica serie di ritratti papali della basilica di S. Paolo fuori le Mura. Città del Vaticano: Pontificio Istituto di Archeologia Cristiana.

Diefenbach, S. 2007. Römische Erinnerungsräume. Heiligenmemoria und kollektive Identitäten im Rom des 3. bis 5. Jahrhunderts n. Chr. Berlin: De Gruyter.

Eastman, D. L. 2011. Paul the Martyr: The Cult of the Apostle in the Latin West. Atlanta: SBL Press.

Ferrua, A. 1942. Epigrammata damasiana. Città del Vaticano: Pontificio Istituto di Archeologia Cristiana.

Friedrichs, K. 2015. Episcopus plebi Dei. Die Repräsentation der frühchristlichen Päpste. Regensburg: Schnell+Steiner.

Geertman, H. A. A. P. 1987. Forze centrifughe e centripete nella Roma cristiana. RPAA 59: 63-91.

Gianandrea, M. 2016. Il V secolo, in: La committenza artistica die papi a Roma nel Medioevo, ed. M. d'Onofrio, 73-108. Roma: Viella.

Grig, L. 2004a. Portraits, pontiffs and the Christianisation of fourth century Rome. Papers of the British School in Rome 72: 203-30.

Guarducci, M. 1967. Hier ist Petrus. Regensburg: Josef Habbel 1967.

Günther, O. 1895-1898. Epistulae imperatorum pontificum aliorum inde ab a. CCCLXVII usque ad a. DLIII datae. Avellana quae dicitur collectio. Wien: Tempsky.

Handl, A. 2016. Viktor I. (189?-199?) von Rom und die Entstehung des „monarchischen“ Episkopats in Rom. Sacris Erudiri 55: 7-56.

Jastrzebowska, E. 2002. S. Sebastiano. La più antica basilica cristiana di Roma. In Ecclesiae urbis, ed. F. Guidobaldi \& A. G. Guidobaldi, 1141-55. Città del Vaticano: Pontificio Istituto di Archeologia Cristiana.

Kessler, H. L. 2004. Séroux's Decadent Column Capital and other Pieces in the Puzzle of S. Paolo fuori le mura. Arte Medievale NS 3,1:9-34.

Klauser, T. 1983. Die Anfänge der römischen Bischofsliste. In Gesammelte Arbeiten zur Literaturgeschichte, Kirchengeschichte und christlichen Archäologie, ed. E. Dassmann, 121-38. Münster: Aschendorffsche Verlagsbuchhandlung.

Krautheimer, R. 1983. Three christian capitals. Berkeley: University of California Press.

Kritzinger, P. 2016. Ursprung und Ausgestaltung bischöflicher Repräsentation. Stuttgart: Steiner. 
Ladner, G. B. (1941) Die Papstbildnisse des Altertums und des Mittelalters. Città del Vaticano: Pontificio istituto di archeologia cristiana.

La Rocca, E. 2002. Le basiliche cristiane 'a deambulatorio' e la sopravvivenza del culto eroico. In Ecclesiae urbis, ed. F. Guidobaldi \& A. G. Guidobaldi, 1109-40. Città del Vaticano: Pontificio Istituto di Archeologia Cristiana.

Leeb, R. 1992. Konstantin und Christus. Die Verchristlichung der imperialen Repräsentation unter Konstantin dem Großen im Spiegel seiner Kirchenpolitik und seines Selbstverständnisses als christlicher Kaiser. Berlin: De Gruyter.

Lucherini, V. 2016. Il IV secolo, in: La committenza artistica die papi a Roma nel Medioevo, ed. M. d'Onofrio, 51-72. Roma: Viella.

Maccarone, M. 1991a. Sedes apostolica - vicarius Petri. In: Il primato del vescovo di Roma nel primo millennio, ed. M. Maccarone, 275-362. Città del Vaticano: Libreria Editrice Vaticana.

Pöpper, T. 2004. Zum Stifterbild des Johannes VI. Levita im verlorenen Apostelzyklus von Alt-St. Paul in Rom. Arte Medievale 3,1: 35-48.

Proverbio, C. 2016. I cicli affrescati paleocristiani di San Pietro in Vaticano e San Paolo fuori le mura. Turnhout: Brepols.

Sessa, K. 2012: The formation of papal authority in late antique Italy. Cambridge: Cambridge University Press.

Schöllgen, G. 1986: Monepiskopat und monarchischer Episkopat. Zeitschrift für die neutestamentliche Wissenschaft 77: 146-151.

Schumacher, W. N./ Barth, T. 1986. Das Baptisterium von Alt-St. Peter und seine Probleme. in: Studien zur spätantiken und byzantinischen Kunst, ed. O. Feld. vol. 1: 215-233. Bonn: Habelt.

Sluiter, I. 2017. Anchoring Innovation: a classical research agenda. European Review 25,1: $20-38$.

Smith, C. 1988 Pope Damasus' baptistery in St. Peter's reconsidered. Rivista di archeologia Cristiana 64: 257-276.

Thiel, A. 1868. Epistolae Romanorum pontificum genuinae et quae ad eos scriptae sunt a S. Hilaro usque ad Pelagium II. Braunsberg: Peter.

Thümmel, H. G. 1999. Die Memorien für Petrus und Paulus in Rom. Berlin/New York: de Gruyter.

Trinci Cecchelli, M. M. 1983. Intorno ai complessi battesimali di S. Pietro in Vaticano e di S. Agnese sulla Via Nomentana. QIASA 3: 181-99.

Ullmann, W. 196o. Leo I and the Theme of Papal Primacy.JThS N.S. 11: 25-51.

Ullmann, W. 1981. Gelasius I. (492-496). Das Papsttum an der Wende der Spätantike zum Mittelalter. Stuttgart: Hiersemann.

Videbech, C. 2017. Anchoring Innovations in Rome from the 4th-6th Century: The Case of the Basilica of St. Peter. Accessible online at http://www.ru.nl/oikos/ 
anchoring-innovation/anchoring-scholarship/anchoring-sanctity-masterclass/ proceedings-workshop-anchoring-sanctity/ (21.11.2017).

Wirbelauer, E. 1993. Zwei Päpste in Rom: Der Konflikt zwischen Laurentius und Symmachus (498-514). München: tuduv.

Zwierlein, O. 2009. Petrus in Rom: Die literarischen Zeugnisse. Berlin: De Gruyter. 